\title{
Hård yta men mjukt innanmäte. Om hur chefer inom den sociala barnavården översätter evidensbaserat socialt arbete till lokal praktik
}

\section{TOMMY LUNDSTRÖM \& EMELIE SHANKS}

I artikeln diskuteras hur mellanchefer $i$ socialtjänstens sociala barnavård ser på evidensbaserad praktik och hur de försöker översätta detta program till sin lokala verklighet.

I socialvetenskaplig tidskrift nr 3, 2011 analyserar Lina Ponnert och Kerstin Svensson hur en så kallad evidensbaserad intervention - föräldrautbildningen Komet - sprids och förändras när den möter nya organisatoriska förhållanden. De bygger sin analys på nyinstitutionell organisationsteori som de använder för att diskutera villkoren och svårigheterna med att översätta

Tommy Lundström, professor, Institutionen för socialt arbete. Stockholms universitet.

Emelie Shanks, doktorand, Institutionen för socialt arbete, Stockolms universitet. ett program från en organisatorisk kontext till en annan. Den här artikeln har liknande utgångspunkter, men koncentreras till hur spridning av ett betydligt mer omfattande program nämligen Evidensbaserat socialt arbete går till i kommunernas sociala barnavård.

Evidensbaserat socialt arbete eller Evidensbaserad praktik (EBP) kan beskrivas som ett övergripande program vars syfte är att förändra det sociala arbetet i riktning mot en professionell praktik, där interventioner vars resultat har vetenskapligt stöd skall få större utrymme. Det vetenskapliga 
stöd som den evidensbaserade praktiken i första hand skall luta sig mot, är utvärderingar av specifika interventioner, helst genomförda med hjälp av randomiserade kontrollerade experiment. En intervention som Kometprogrammet skulle med andra ord kunna utgöra en delmängd av EBP (Bergmark, Bergmark \& Lundström 2011). Ponnerts och Svenssons artikel om Komet har därmed ett något snävare fokus än den föreliggande artikeln. De intresserar sig för ett specifikt programs spridning i en speciell kontext - Statens institutionsstyrelses ungdomshem (Ponnert \& Svensson 2011). I den här artikeln granskas hur ett betydligt mer omfattande program tas emot av kommunernas barnavårdsorganisationer.

Syftet med artikeln är att undersöka hur chefer inom socialtjänstens sociala barnavård ser på evidensprogrammet och hur de söker översätta EBP till sin lokala praktik. Att fokus ligger på barnavården motiveras av att det är det största verksamhetsområdet $\mathrm{i}$ svenskt socialt arbete och att det är relativt välutforskat. Det borde därför vara ett område där en internationell evidensbaserad forskningsfront skulle vara framträdande. Att cheferna står i centrum motiveras med att de ofta beskrivs som en nyckelgrupp för implementering av EBP (Socialstyrelsen 2012a, b). I denna artikel koncentreras uppmärksamheten till (1) de chefer som har direkt ansvar för den sociala barnavården i kommuner eller kommundelar, de arbetar för det mesta under socialchefen eller chefen för individ och familjeomsorgen och kallas ofta för enhetchefer, samt (2) första linjens chefer som t.ex. kan vara ansvariga för en barn- eller ungdomsgrupp och som befinner sig närmast social- arbetarna i hierarkin, de kallas ofta förste socialsekreterare. Dessa båda chefskategorier är alltså de som har att hantera evidensfrågorna i vardagen och som har en nyckelroll för implementering.

Den analys som presenteras i artikeln hoppas vi skall bidra till att öka kunskapen när det gäller villkoren för att introducera ett komplext program som EBP med standardisering av arbetssätt och arbetsmetoder som ett övergripande mål, i ett organisatoriskt fält där de enskilda organisatoriska enheterna har hög grad av självbestämmanderätt och där de professionella traditionellt haft relativt hög grad av diskretion. Artikeln kan förhoppningsvis också bidra till diskussioner om chefernas roll i implementeringen av nya program på det sociala arbetets och angränsande fält. Även om EBP med sina anspråk på en i grunden förändrad professionell praktik är mycket långtgående, finns troligen en del gemensamma drag mellan spridningen av detta program och andra försök att från centralt håll introducera program på organisatoriska fält med förhållandevis svag vetenskaplig bas och hög grad av lokalt självbestämmande. Avslutningsvis i artikeln diskuteras förutsättningarna för EBP programmets överlevnad och framgång.

\section{EBP som program}

Många andra program vars spridning har undersökts med nyinstitutionell organisationsteori kan beskrivas som relativt mjuka och inte särskilt distinkta till sitt innehåll. Det gäller till exempel olika typer av ledarskaps- och managementmodeller (Sahlin \&

Tommy Lundström \& Emelie Shanks: Hård yta men mjukt innanmäte. 
Wedlin 2008). Med EBP förhåller det sig något annorlunda. Det är ett program med en hård $y t a$, men om man skrapar en smula på skalet framträder ett tämligen mjukt innanmäte. Ytligt sett framträder EBP som ett rationellt och vetenskapligt program. I sin ursprungliga form innebär det att med hjälp av hårda data om vilka interventioner som fungerar bäst skall det sociala arbetets innehåll förändras i vetenskaplig riktning och därmed skall hjälpen till klienterna förbättras. På basis av vetenskap skall ineffektiva och skadliga interventioner utmönstras och ersättas av mer effektiva metoder. Ofta beskrivs EBP som ett arbetssätt vilket vilar på tre ben: (1) den professionelles egen erfarenhet, (2) klienternas synpunkter och (3) evidensen, dvs. de vetenskapliga bevisen. Sammanvägda utgör dessa tre ben ett evidensbaserat arbetssätt (Oscarsson 2009).

För det sociala arbetets del representerar de två första benen inget nytt. Vad som däremot utgör en påtaglig nyhet är imperativet att basera interventioner på bästa möjliga vetenskapliga kunskap om effekter. Oftast hänvisas till någon form av evidenshierarki, där randomiserade experiment (RCT) sammanställda i systematiska översikter har högst vetenskapligt bevisvärde och där kvasiexperiment möjligen kan ses som acceptabla. I grunden kräver ett fungerande evidensprogram standardiserade regler och överenskommelser om vad som duger som bevis. I det syftet har internationella organisationer som Cochrane och Campbell Collaboration byggts upp och Socialstyrelsen har sett som sin uppgift att sammanställa och sprida kunskap om vilka interventioner som har evidens på det soci- ala arbetets område (www.socialstyrelsen. se/evidensbaseradpraktik).

Att innanmätet i detta till ytan hårda program kan beskrivas som mjukt och odistinkt handlar dels om motsättningar kring vad EBP faktiskt är, dels om det faktum att det som borde vara en hård kärna, nämligen närvaron av en serie väl utprövade evidensbaserade interventioner, vid närmare påseende inte visar sig finnas i verkligheten. Motsättningarna märks bland annat i diskussioner om huruvida EBP skall ses som ett projekt underifrån, där socialarbetarna själva skall vara de som kritiskt granskar evidensläget och tillämpar de evidensbaserade interventioner de finner lämpliga, eller om socialarbetarna skall styras uppifrån genom riktlinjer och manualer. Frånvaro av vetenskapligt utprövade interventioner som fungerar bättre än andra är naturligtvis ett grundproblem om man skall tillämpa EBP. På den sociala barna- och ungdomsvårdens område är frånvaron uppenbar vare sig man studerar det svenska eller internationella forskningsläget. Sammantaget finns mycket lite att hålla sig till för socialarbetare som vill arbeta evidensbaserat, åtminstone om de håller sig till etablerade evidensproducenter som Socialstyrelsen, SBU och Campbell Collaboration (för en genomgång av kunskapsläget se Bergmark, Bergmark \& Lundström 2011 s. 95-117).

\section{EBP som top-down projekt}

I Sverige har EBP kommit att bli ett topdown projekt där Socialstyrelsen uppifrån och nedåt försöker förändra socialt arbete i evidensriktning (Sundell \& Rose- 
lius 2008). Allmänt sett kan man säga att en spridning och förankring av EBP innehåller två sammanläkande men åtskiljbara element. För det första en förankring av programmets programmatiska eller normativa bas, dess politiska rationalitet om man så vill, och för det andra en spridning av dess teknologiska eller operationella delar, det vill säga i detta fall de specifika evidensbaserade interventionerna. Givetvis hänger dessa båda element samman och det är i samspelet mellan dem som statlig styrning av den sociala barnavården kan bli begriplig (se Rose \& Miller 1992; Power 1997). Sett ur ett sådant perspektiv innebär det första momentet att Socialstyrelsen presenterar argument av typen: (1) socialtjänstens klienter bör få tillgång till bästa möjliga insatser samt (2) det är etiskt motiverat att arbeta evidensbaserat eftersom metoder som inte prövats vetenskapligt kan vara verkningslösa, eller i värsta fall direkt skadliga för klienterna (Sundell \& Soydan 2008). Det programmatiska elementet handlar med andra ord om att få socialarbetare att omfatta idén om en evidensbaserad praktik. Argumentationen är framförallt normativ och värdegrundad.

Det andra elementet i den statliga styrningen handlar om att sprida evidensbaserade interventioner. Här uppstår en serie problem som har att göra dels med frånvaron av interventioner att sprida, dels med att det är svårt att ens i teorin toppstyra svenska kommuner. Ett av de försök som gjorts är att Socialstyrelsen via sin hemsida i en så kallad metodguide presenterar interventioner som utsatts för vetenskaplig prövning. Man för också fram implementeringsstrategier där chefer och ledare på olika nivåer spelar en central roll för att se till att EBP blir en del av den ordinarie verksamheten. Spridning av evidensbaserade interventioner innebär teoretiskt och idealt sett standardisering i två avseenden, dels i meningen att de bästa interventionerna tilllämpas överallt, dels att de tillämpas på likartat sätt, gärna via manualer eller styrande riktlinjer (Sundell \& Roselius 2008; Socialstyrelsen 2012a, b).

Givetvis inrymmer Socialstyrelsen implementering av EBP en paradox. Socialarbetare uppmanas att tillämpa ett övergripande program vars yta framstår som rationell och för många dessutom som aptitlig, men vars innehåll i form av vetenskapligt väl utprövade interventioner i stort sett är frånvarande. Att översätta ett sådant program till lokal verklighet kräver manövrerande, kompromisser och anpassningar från de som är mottagare.

\section{Om att översätta och redigera idéer}

EBP kan sägas utgöra en del av en större och mer omfattande rörelse i riktning mot förvetenskapligande av en serie olika praktikfält. Evidensrörelsen startade i medicinen någon gång i skiftet mellan 1980- och 1990-tal och har sedan spritt sig till ett antal olika professioner. Idag talar man om evidensbaserad praktik inom lärarkåren, bland sjuksköterskor arbetsterapeuter osv, men det förekommer också försök att introducera evidensbaserad management och evidensbaserad politik. I den meningen är EBP en stark institutionell kraft också utanför det sociala arbetet (Bergmark, 
Bergmark \& Lundström 2011; Bohlin \& Sager 2011; Sahlin \& Wedlin 2008).

Hur spridning av mer eller mindre sammanhållna idéer eller program går till har varit av särskilt intresse för organisationsteoretiker från olika akademiska discipliner. Sahlin och Wedlin (2008) pekar på att forskare från de nordiska länderna intresserat sig för de dynamiska processer som uppstår när idéer cirkuleras och sprids. Viktigt i det sammanhanget är hur idéer översätts när de flyttas från ett organisatoriskt sammanhang till ett annat och vad som faktiskt händer med organisationerna när de konfronteras med nya idéer. Centrala begrepp är översättning och redigering. När idéer möter nya aktörer, organisationer och andra idéer behöver de översättas för att bli användbara. Begreppet redigering tar fasta på hur sådana översättningsprocesser går till, vilka som redigerar och hur de gör när de redigerar. I tidigare organisationsteoretisk forskning har man fokuserat på hur nya idéer, när de institutionaliserats, tenderar att åtminstone på ytan homogenisera organisationer och arbetssätt, snarare än på hur idéerna som sådana tenderar att förändras och anpassas när de möter nya sammanhang (Johansson 2001).

När det gäller EBP är frågan om homogenisering kontra adaption och förändring särskilt intressant, eftersom en bärande tankegång är att de som tillämpar evidensbaserade interventioner skall göra lika. De ofta manualbaserade interventioner som brukar rekommenderas av förespråkarna, kräver en faktisk homogenisering och standardisering av arbetssätt och det sätt som arbetet organiseras, för att de skall fungera som tänkt. I det sammanhanget blir det naturligtvis särskilt intressant att studera hur evidensprogrammet redigeras när det når skilda organisatoriska sammanhang.

I socialt arbete talar man ofta om att nya arbetsmetoder sprids som moden via imitation. Tidigare "moderörelser" som systemteoretiska arbetssätt eller lösningsfokuserat socialt arbete har inte haft särskilt tydliga avsändare utan har spridits via imitativa processer från en kommun till en annan, där kommuner imiterar varandra och där konsulter och andra bärare av idéerna fungerat som medier. De har kunnat bli kraftfulla under tiden de spridits, genom att de fått stöd från viktiga aktörer och/eller för att de passat in i tiden (se Røvik 2000; Grape, Johansson, \& Blom 2006; Sahlin \& Wedlin 2008).

När det gäller EBP förhåller det sig annorlunda, här finns på svensk botten en tydlig och kraftfull avsändare i form av Socialstyrelsen. ${ }^{1}$ Till skillnad från spridning som en rörelse som förs vidare genom imitation i en kedja och genom medier i form av bl. a. konsulter, finns således en central modell och en färdig uppsättning idéer som kan plockas upp av olika aktörer och inkluderas i skilda praktiker. Imitation via en central modell (det Sahlin och Wedlin kallar broadcasting) bör rimligen, allting annat lika, skapa större förutsätt-

1 Det är givetvis möjligt att betrakta Socialstyrelsen som en medierande organisation (Sahlin \& Wedlin 2010) mellan å ena sidan evidensproducenter inom och utanför Sveriges gränser och å andra sidan barnavårdens lokala organisationer. Socialstyrelsens starka organisatoriska position och sammanhållna programmatiska ställningstagande gör det rimligt att tala om dem som en självständig aktör snarare än en förmedlare. 
ningar för homogenisering än vad som är fallet för imitation via kedjerörelse. Men samtidigt finns svårigheter att imitera ett program som har tydliga motsättningar och otydligheter inbyggt i sig. Vilka konsekvenser det har och vilka slutsatser det bör leda till mer generellt kommer att diskuteras avslutningsvis i artikeln.

\section{Metod och urval}

Artikelns kvantitativa data utgörs av en del av ett större enkätmaterial. Enkätundersökningen i sin helhet har riktats till ett representativt urval av chefer inom samtliga områden av socialtjänstens individoch familjeomsorg. Cheferna som ingick i denna enkätundersökning identifierades med hjälp av akademikerförbundet SSR:s medlemsregister. Akademikerförbundet SSR organiserar majoriteten av alla socialarbetare i Sverige, närmare bestämt ungefär $80 \%$. En stor del av de övriga är anslutna till TCO-förbundet Vision (f.d. SKTF). Föreliggande urvalsförfarande innebär att vi inte kan generalisera våra resultat till de chefer inom kommunernas individ- och familjeomsorg som är anslutna till andra fackförbund, alternativt som inte är fackligt anslutna. ${ }^{2}$

Cheferna var vid tiden för undersökningen registrerade som yrkesverksamma mellanchefer (dvs. första, andra och tredje linjens chefer) inom socialtjänsten individoch familjeomsorg. Det totala antalet som

2 Samma urvalsbas har tidigare använts av Bergmark och Lundström (2008) och Höjer och Dellgran (2005) för studier av socialarbetare. passade in i ovanstående kategorier var 1.414. Från denna population gjordes ett slumpvis urval om 900 chefer. Under våren 2010 skickades enkäten per post till dessa chefers hemadresser. Efter påminnelser inkom svar från 644 individer, vilket ger en svarsfrekvens på 71,5\%. Eftersom ett antal av de individer som svarat inte kunde anses tillhöra undersökningsgruppen (totalt inkom 242 enkäter med meddelandet att respondenten inte arbetar som chef inom individ- och familjeomsorgen) baseras resultaten av den fullständiga enkätundersökningen på 402 enkäter. $^{3}$

Innehållet i enkäten har utvecklats dels på basis av tidigare studier (se Bergmark \& Lundström, 2002, 2005, 2008), dels på erfarenheter och kunskaper från de kvalitativa intervjuerna (se nedan). Innan enkäten skickades ut prövades den på ett mindre antal chefer inom socialtjänstens individoch familjeomsorg.

Förutom bakgrundsfrågor om t.ex. chefernas arbetslivserfarenhet och utbildning berörde enkäten områden som organisationens struktur, chefs-/ledarskapsutbildningar, chefernas upplevelse av sitt och andra aktörers inflytande över organisatio-

3 Det framkom att SSR inte hade möjlighet att urskilja chefer som arbetade inom individ- och familjeomsorgen (dvs. framförallt med försörjningsstöd, missbruk och barnavård) från dem som arbetade inom exempelvis handikappsomsorg. Detta innebar att enkäten skickades ut till ett antal chefer som inte tillhörde populationen. Vidare var medlemsregistret inte helt uppdaterat, vilket innebar att ett antal individer som stod registrerade som chefer inom social omsorg inte längre var yrkesverksamma som sådana. 
nen, arbetsvillkor samt metodanvändande och evidensbaserad praktik.

Från den fullständiga enkätundersökningen har första och andra linjens chefer som arbetar med social barnavård valts ut som underlag för denna artikel. Det handlar om sammanlagt 192 individer som presenteras närmare i Tabell 1 .

Könsfördelningen är som man kan förvänta sig att den skall vara i en undersökning av socialarbetare. De allra flesta även på chefsnivå är kvinnor. Andelen första linjens chefer är, föga förvånande fler än andra linjens chefer. De ansvariga för en barnavårdsenhet har med andra ord ofta ett par första linjens chefer som underställda. De allra flesta respondenter har socionomexamen och drygt en tredjedel har dessutom studerat vidare minst en termin på universitet. Det sistnämnda kan handla om kurser med inriktning specifikt på barnavårdsfrågor, men också utbildningar i t.ex. ledarskap. De flesta chefer är mycket erfarna, en majoritet har arbetat men är 20 år inom kommunal socialtjänst. I övrigt kan sägas (ej i tabell) att omkring 75 procent arbetar i kommuner med 50.000 invånare eller fler, men 12 procent arbetar i små kommuner (färre än 25.000 invånare). Nio av tio arbetar renodlat med social barnavård antingen som chefer för sådana enheter eller med ansvar för delar av enheterna, t.ex. med särskilt ansvar för ungdomsfrågor eller liknande. De övriga tio procenten kombinerar sitt chefskap för barnavårdsfrågor med ansvar för försörjningsstödfrågor och/eller missbrukarvård.

Det kvalitativa materialet består av en serie om sju intervjuer med första och andra linjens chefer i social barnavård. Dessa intervjuer genomfördes under hösten 2008 och våren 2009. Fyra av de intervjuade cheferna var första linjens chefer och de övriga tre andra linjens chefer. Cheferna kommer från sex olika kommuner i Mellansverige (en storstad, två förorter, två mellanstora kommuner och en mindre kommun (nedan benämnda kommun A-F).

Analysen av det kvantitativa materialet presenteras i form av enkla frekvenstabeller som behandlar bland annat chefernas syn på EBP, deras egen och andras betydelse

\section{Tabell I.}

Undersökningsgruppen i enkätstudien ( $n=192)$.

\begin{tabular}{llr}
\hline Kön & Kvinnor & $86 \%$ \\
& Män & $14 \%$ \\
\hline Position & Första linjen (t.ex. förste socialsekreterare) & $65 \%$ \\
& Andra linjen (t.ex. enhetschefer) & $35 \%$ \\
\hline Utbildning & Socionomexamen & $92 \%$ \\
& Annan universitetsutbildning & $8 \%$ \\
& & \\
& En termins högskolestudier eller mer efter examen & $38 \%$ \\
\hline Erfarenhet av arbete inom & 10 år eller mindre & $13 \%$ \\
kommunal socialtjänst & II -20 år & $36 \%$ \\
& Mer än 20 år & $51 \%$ \\
\hline
\end{tabular}


som översättare av programmet samt vilka evidensbaserade interventioner de tillämpar. Analysen av de kvalitativa intervjuerna har utgått från det teoretiska ramverket och tillvägagångssättet är därmed mer deduktivt än induktivt. Båda artikelförfattarna har noggrant läst igenom intervjuerna och på basis av de teoretiska utgångspunkterna letat efter utsagor om:

1. Hur cheferna ser på sin egen och andras (politiker, högre chefer, underställdas) roll som introduktörer och översättare av EBP?

2. Hur cheferna ser på EBPs programmatiska innehåll och hur de menar att programmet mottagits på arbetsplatserna?

3. Hur cheferna ser på EBPs teknologiska eller instrumentella delar. Vad ses som evidensbaserade metoder och vilka tillämpas?

I analysarbetet har vi var och en för sig och i gemensamma diskussioner lagt särskilt vikt vid att identifiera motsättningar, likheter, olikheter och konflikter kring EBP. Detta just för identifiera olikheter i översättning och redigering, som inte kunnat fångas i det kvantitativa materialet. När vi citerar de intervjuade har vi utgått från sakinnehållet, snarare än från hur utsagor görs. Det betyder också att citatet är redigerade så att vissa småord, upprepningar och liknande strukits.

\section{Resultat}

Vi inleder resultatgenomgången genom att diskutera hur cheferna ser på sig själva som aktörer när det gäller att introducera sina idéer, sedan presenteras chefernas syn på evidensprojektet som helhet, dvs. hur de översätter evidensprojektets normativa och programmatiska bas. Avslutningsvis diskuteras den instrumentella eller tekniska sidan av spridningen och översättningen, nämligen vilka evidensbaserade metoder man säger sig tillämpa och hur man ser på dem. Spridningen av EBP kan beskrivas som en pågående institutionaliseringsprocess där programmet ännu inte "satt sig". Som genomgående teman diskuteras hur cheferna hanterar motsättningar och andra problem i översättningen av EBP till lokala förhållanden, under en sådan process.

\section{Chefernas betydelse}

För att få ett grepp om vilken betydelse cheferna ger sig själva och andra för introducerandet av nya idéer, tillfrågades de om vilka som kommer med förslag om nya arbetssätt på barnavårdsområdet. Resultaten redo-

\section{Tabell 2.}

Från vilka kom i första hand idéer om nytt arbetssätt (infört under de senaste tre åren), procent $(n=135)^{*}$

\begin{tabular}{lr}
\hline Dig själv & 30,4 \\
Politiker inom kommunen & 5,2 \\
Andra chefer & 33,3 \\
Medarbetare & 19,3 \\
Annan & 11,9 \\
\hline Summa & 100,0 \\
\hline \multirow{2}{*}{135 av 192 har besvarat frågan, 35 har angett att inget } \\
nytt arbetssätt genomförts och övrigt bortfall handlar \\
främst om de som svarat "vet ej". En mindre del av de som \\
svarat"dig själv" har markerat"dig själv" tillsammans med \\
annan chef eller medarbetare, och en mindre del av de \\
som markerat chefer har angett att initiativet tagits av \\
andra chefer i förening och/eller med medmedarbetare.
\end{tabular}

Tommy Lundström \& Emelie Shanks: Hård yta men mjukt innanmäte. 
visas i Tabell 2. Nära nog två tredjedelar ger sig själva (30,4\%) eller andra chefer $(33,5 \%)$ stor betydelse i sammanhanget. Skall man tro dessa första och andra linjens chefer, så är det de och deras närmast överordnade som driver organisationerna framåt, åtminstone när det gäller att introducera nya arbetssätt. Medarbetare, dvs. vanliga socialsekreterare har också en viss betydelse i sammanhanget medan politiker ges en mycket undanskymd roll. Några har angett "annan", det vanligaste svaret här är Socialstyrelsen. Chefernas svar understryker att de själva ser sig som betydelsefulla aktörer i spridning av nya program och idéer inom sitt fält. I linje alltså med vad som förväntas av dem från $t$ ex Socialstyrelsens (2012a, b).

I de kvalitativa intervjuerna kan man, från en av de intervjuade, få en något annorlunda bild av politikernas inflytande, kanske särskilt i gränslinjen mellan programmatisk och teknologisk påverkan. Följande citat visar på en viss komplexitet i relationerna mellan politiker och tjänstemän på olika nivåer:

Vi vill utveckla en kunskapsbaserad socialtiänst, vi vill se till /.../ att man använder de bästa metoder som man känner till. Det är en väldigt stark vilja från politiker, det är en stark vilja frän ledning. Personalen försöker få ihop det här, för att jag tror inte att det finns några motsättningar när det gäller personalen, men det finns en viss försiktighet: ska vi verkligen använda oss av alla de här manualbaserade eller strukturerade metoderna? Vad är det som händer med socialarbetaren? Hur stel ska man vara? (Andra linjens chef, kommun C)
Såväl "ledning" som politiker trycker på, medan personalen försöker få ihop det, även om det finns en "viss försiktighet". Man kan också notera en redigering av det grundläggande begreppet genom att den intervjuade chefen använder det i förhållande till EBP mindre förpliktigande "kunskapsbaserad socialtjänst". Men här märks också det uppenbara problemet för tjänstemännen att "få ihop" de teknologiska delarna (som man uppfattar dem), med den lokala verkligheten - "hur stel ska man vara?".

\section{Den programmatiska sidan av saken}

Av Tabell 3 framgår att nästan alla chefer hört talas om evidensbaserat socialt arbete. Något annat hade snarast varit förvånande. Begreppet har fått fäste i socialt arbete, vilket en serie tidigare undersökningar riktade till socialarbetare i socialtjänsten också visat. Fyra femtedelar av cheferna tycker dessutom att deras verksamhet behöver tydligare vetenskaplig koppling, det är till och med ett något starkare instämmande än vad som framkommit i tidigare undersökningar (Bergmark \& Lundström 2002, 2007, 2008). Det är bara en handfull av respondenterna som inte tycker att EBP hör hemma i socialt arbete. De allra flesta verkar med andra ord ha accepterat programmet i en mer allmän, programmatisk mening. I detta normativa eller politiska avseende har Socialstyrelsens "broadcasting" fungerat väl.

Något mer komplicerat blir det dock när man i en enkätfråga sätter vetenskapligt utformade interventioner i motsätt- 
ning till socialt arbete som "unika möten mellan människor". Då är det en ganska stor grupp, omkring en fjärdedel bland barnavårdscheferna, som kan se problem med kopplingen mellan å ena sidan EBP:s "hårda skal" i form av (alltför stelbenta?) vetenskapligt framtagna metoder och å andra sidan det man ibland kallar relationsbaserat socialt arbete eller benämner tyst kunskap. Förhållandet mellan svaren på de tre första frågorna och svaren på den på den sista frågan i Tabell 3, säger därför kanske något om spänningen mellan hur väl evidensprojektets övergripande allmänna grundtanke om att socialt arbete i högre grad borde baseras på vetenskap förankrats, och hur relativt sett svårare det kan vara att översätta de mer tekniska delarna. I teoretiska termer visar svaren också att EBP än så länge knappast kan beskrivas som ett helt och hållet institutionaliserat program. De normativa, programmatiska delarna har till stora delar anammats, men programmet har inte institutionaliserats i den meningen att det föreligger en automatisk anpassning till tankessätt och arbetsmodeller. I ett läge när en institutionaliseringsprocess fortfarande pågår, finns visst utrymme för motstånd och aktörer som håller fast vid andra (institutionella) tankesätt (DiMaggio 1988; Powell 1991; Seo \& Creed 2002).

Nästan alla är alltså positiva till evidensprojektet i allmänna termer, men nära nog två tredjedelar önskar mer vägledning från Socialstyrelsen i vad de faktiskt skall göra. De vill ha mer riktlinjer om vilka metoder de skall använda. Det kan vara uttryck både för det faktum att många faktiskt vill bli styrda uppifrån, det vill säga att de själva ser på EBP som ett top-down projekt och är positiva till det, men också för att det i en mer rationell och logisk mening är helt rimligt att önska sig evidensbaserade interventioner när man anammat den programmatiska, normativa delen av projektet.

I de kvalitativa intervjuerna framträder en mer komplex bild än i svaren på enkätfrågorna. En del av de intervjuades tanke-

\section{Tabell 3.}

Inställningen till EBP ( $n=188-192)$.

\begin{tabular}{|c|c|c|}
\hline Har du hört talas om EBP? & $\begin{array}{l}\mathrm{Ja} \\
\mathrm{Nej}\end{array}$ & $\begin{array}{r}95,8 \% \\
4,2 \% \\
\end{array}$ \\
\hline $\begin{array}{l}\text { Vid min arbetsplats behöver verksamheten få en } \\
\text { tydligare koppling till metoder som är vetenskapligt } \\
\text { utprövade }\end{array}$ & $\begin{array}{l}\text { Instämmer helt eller i viss mån } \\
\text { Neutrala/tar avstånd }\end{array}$ & $\begin{array}{l}80,0 \% \\
20,0 \%\end{array}$ \\
\hline $\begin{array}{l}\text { Evidensbaserad praktik hör inte hemma i socialt } \\
\text { arbete }\end{array}$ & $\begin{array}{l}\text { Instämmer helt eller i viss mån } \\
\text { Neutrala/tar avstånd }\end{array}$ & $\begin{array}{r}1,6 \% \\
98,4 \% \\
\end{array}$ \\
\hline $\begin{array}{l}\text { Socialt arbete handlar i huvudsak om unika möten } \\
\text { mellan människor vilket gör vetenskapligt utformade } \\
\text { metoder mindre användbara }\end{array}$ & $\begin{array}{l}\text { Instämmer helt eller i viss mån } \\
\text { Neutrala/tar avstånd }\end{array}$ & $\begin{array}{l}26,6 \% \\
74,4 \%\end{array}$ \\
\hline $\begin{array}{l}\text { Det vore önskvärt med tydligare riktlinjer från social- } \\
\text { styrelsen om vilka metoder som skall användas i soci- } \\
\text { alt arbete }\end{array}$ & $\begin{array}{l}\text { Instämmer helt eller i viss mån } \\
\text { Neutrala/tar avstånd }\end{array}$ & $\begin{array}{l}65,2 \% \\
34,8 \%\end{array}$ \\
\hline
\end{tabular}

Tommy Lundström \& Emelie Shanks: Hård yta men mjukt innanmäte. 
gångar ligger emellertid helt $\mathrm{i}$ linje med enkätsvaren. På frågan "Vad tror du att inställningen /till EBP/ är?", blir svaret från en av de intervjuade:

\section{Jo de/socialarbetarna/ vill det här.}

\section{I... I}

$J a$, det ligger ju $i$ att kunna bli stolt över sitt arbete och kunna påvisa resultat och speciellt de nya socionomerna, de är för det här. (Andra linjens chef, kommun E)

Denna andra linjens chef markerar en påtagligt positiv attityd, särskilt bland de nyutbildade socionomerna. Delvis verkar EBP kunna ses som en hävstång för att få en starkare professionell ställning, man skall kunna vara stolt över sitt arbete och det blir man om man via EBP kan påvisa resultat. Samma chef (som vid intervjutillfället deltar i en forskningscirkel om EBP) ser emellertid också evidens som något som man måste förhandla fram betydelsen av:

Ja det är ju jätteviktigt, men svårt. Alltså det gäller ju bara att enas kring vad evidens är och hur ser vi på det och det måste man ju först av all definiera. Så det har jag tagit upp att jag tycker att vi behöver göra i ledningsgruppen. Ja... Det handlar ju väldigt mycket om pengar $i$ ledningsgruppen och det kan man bli lite trött på, så det gäller ju att få in de här frågorna, speciellt i de här tiderna. (Andra linjens chef, kommun E)

Vad som är evidens och hur man skall se på det görs med andra ord till en fråga för ledningsgruppen, något som bör bli föremål för uttolkning, förhandling och redigering.
Det är också intressant att notera hur svårt det är att få tid med evidensfrågorna. De konkurrerar med ekonomin och det saknas bra organisering för att ta hand om dem. EBP blir därmed en fråga bland andra, inte något som genomsyrar organisationen och det vardagliga arbetet.

Det finns andra chefer som uttrycker en mer uppenbar skepsis. På frågan om EBP diskuteras mycket, blir svaret från en andra linjens chef:

Ja, alltså... eller diskuteras mycket ska jag inte säga, /.../, men det händer då och då att vi pratar om: /.../ hur man kan mäta? Alltså I.../ hur kan man mäta och i förhällande till vad? Det finns nog många samverkansfaktorer sompåverkar, så ibland undrar jag /.../ hur går det att mäta och i förhällande till vad? (Andra linjens chef, kommun F)

Här beskrivs evidensprojektet som något som i första hand handlar om att kunna mäta effekterna av vad socialarbetarna gör. Detta samtidigt som den intervjuade chefen uttrycker stor skepsis om möjligheterna att mäta, eftersom samband kan vara svåra att uttolka.

En annan av de intervjuade cheferna talar i termer av spänningar mellan personal:

I min arbetsgrupp så finns det de som är /... skeptiker, det finns de som är för, vill hoppa på varenda evidenståg. Men de flesta vill inte det, de flesta är någonstans mittemellan /.../ hailler sig a jour, men /.../ har jobbat så länge så de håller sig lite laid-back /.... De vet att den beprövade erfarenheten har högt värde tillsammans med evidensen /.../ 
De fär det hett om öronen ibland när det kommer.. någon... evidensivrare... men då är det viktigt tycker jag i min roll, att man inte fär bli /.../ för skeptisk mot det nya, för vi måste ju ta in det nya, men vi måste omförhandla det och göra om det till det som familjerna lever $i .$. (Första linjens chef, kommun B)

Det ovanstående citatet är det tydligaste exemplet på att man talar i termer av faktiska motsättningar eller i vart fall olikartade åsikter i personalgruppen, där man identifierar skeptiker, evidensivrare och de som befinner sig mittemellan. I citatet finns dessutom tankar om att programmet måste redigeras för ett passa i den lokala verkligheten: EBP-interventioner ("det nya") måste "omförhandlas" för att passa i klienternas verklighet. Svaren på dessa intervjufrågor visar liksom enkätsvaren tydligt att EBP är $i$ en process av institutionalisering, $i$ en fas där motstånd fortfarande är möjligt och förhandlingar nödvändiga.

\section{Den teknologiska sidan av saken}

På en enkel enkätfråga om de använder någon evidensbaserad metod i verksamheten så svarar knappt tre fjärdedelar $(73,4$ procent, $n=141$ ) av cheferna ja. I nästa fråga ombads de uppge vilken eller vilka $\mathrm{EB}$ metoder de använde (öppet svarsalternativ). Ett tiotal av de som sagt att de använder EB metoder har valt att inte fylla i vilka interventioner det rör sig om. Det absolut vanligaste svarsalternativet, bland de som svarat på den öppna frågan, är olika former av bedömningsinstrument eller systematiska dokumentationssystem. Ungefär 50 chefer (dvs. en dryg tredjedel av de som uppgett att de jobbat med evidensbaserade metoder) har således angivit bedömningsinstrument som Signs of Safety (riktat till barn) eller Ester, ADAD och Savry (riktat till ungdomar) samt Socialstyrelsens systematiska dokumentationssystem BBIC. ${ }^{4}$ Inget av dessa instrument utgör någon form av intervention för förändring av klienternas förhållanden. Det är med andra ord svårt att se att instrumenten, i egen kraft, kan beskrivas som evidensbaserade interventioner. Forskningsmässigt finns t.ex. inga kunskaper om i vilken grad instrument som dessa och andra bidrar till att, genom upptäckt, förebygga t.ex. barnmisshandel eller ungdomskriminalitet. Däremot kan instrument för riskbedömning samt för identifikation av psykiatrisk problematik och risk- och skyddsfaktorer ses som en del i en evidensbaserad teknologisk apparat. Instrumenten kan således i bästa fall fungera som verktyg för att göra bedömningar av vilka barn och unga som behöver vilka interventioner, vilka som behöver remitteras vidare eller som verktyg för att bedöma hur barnen utvecklas (Lundström 2012).

Föräldrastödsprogram (Komet, Incredible Years, Cope och Föräldrakraft) anges av ungefär 25 chefer, vanligast bland dessa är Komet. Ungefär lika ofta som föräldrastödsprogrammen anges ART (Aggression Replacement Training) och FFT (Funktionell Familjeterapi). I övrigt anges barn- och

4 Den specialintresserade kan hämta information om dessa instrument från $\mathrm{t}$ ex Socialstyrelsens hemsida www.socialstyrelsen.se.

Tommy Lundström \& Emelie Shanks: Hård yta men mjukt innanmäte. 
ungdomsinriktade interventioner som IHF (Intensiv hemmabaserad familjebehandling), Marte Meo, MST (Multisystemisk terapi) och MTFC (Multidimensional Treatment Foster Care). Det förekommer också att man anger mer generella interventioner. Det vanligaste exemplet är MI (Motivational Interviewing) och ibland anges också mer allmänt övergripande teoretiska eller metodologiska perspektiv som kognitiv beteendeterapi, systemteori eller psykodynamiskt förhållningssätt. ${ }^{5}$

I en extremt generös inkludering, där man tar med samtliga metoder som överhuvudtaget prövats i vetenskapliga studier och/eller sådana som beskrivs som i någon mening vetenskapsbaserade av de företag som säljer dem, så kan föräldrastödsprogrammen ART, FFT, MTFC, Marte meo, MST och IHF räknas in i en evidensbaserad grupp. Med detta sätt att räkna, där också vi som skrivit denna artikel gjort en mycket långtgående redigering av evidensbegreppet, så är det drygt 60 chefer (av de totalt 141 som uppgivit att de använder evidensbaserade metoder), som angett "evidensbaserade interventioner" ${ }^{6}$ Det bör också understrykas att det faktum att man uppger att man arbetar med en intervention inte säger något om i vilken utsträckning man gör det eller hur strikt man är i tilllämpningen interventionen ifråga.

5 Den specialintresserade kan hämta information om de flesta av dessa interventioner från $\mathrm{t}$ ex Socialstyrelsens hemsida www.socialstyrelsen.se.

6 Några få av de som svarat på den öppna frågan, har svarat sådant som "många" eller "ett flertal" $i$ stället för att ange någon specifik metod. Dessa har inte räknats med i sammanställningen.
I mer sträng mening, dvs. att de angivna interventionerna visat goda resultat jämfört med andra metoder i systematiska översikter eller i en eller flera välgjorda RCT:er, kan man starkt ifrågasätta om någon av de angivna interventionerna är evidensbaserad. I bästa fall finns motsägelsefulla eller svårtolkade resultat, i inget fall finns entydiga resultat från systematiska översikter. Här är dock inte platsen för en sådan vetenskaplig granskning (läsaren hänvisas till exempelvis Andrée Löfholm et al 2009; Bergmark, Bergmark \& Lundström 2011; Hansson \& Olsson 2012; Kaunitz \& Strandberg 2009). Vad vi kan konstatera är att ett sätt för barnavårdscheferna att hantera spänningen mellan programmatiskt och instrumentellt innehåll är att helt enkelt att inkludera lite av varje i begreppet evidensbaserade metoder. Det är svårt att hitta några systematiska mönster för chefernas angivna metodanvändning. Möjligen kan man säga att de som nämner ett bedömningsinstrument ofta nämner fler än ett och detsamma gäller för interventioner. I några fall kan man hitta mönster som kan tyda på att en viss arbetsplats har kontakt med organisationer som säljer utbildningar i flera "evidensbaserade interventioner". Ett antal chefer nämner till exempel olika kombinationer av interventioner (t.ex. IHF, FFT, Marte Meo) som säljs av företaget Familjeforum (http://www.inom.com/familjeforum/).

EBP har i huvudsak spridits från centralstaten via broadcasting. Det tycks dock som en ny sorts företag, större än tidigare och med ett bredare utbud av tjänster, bidrar till spridning av de teknologiska delarna i form av utbildning i specifika 
interventioner eller utförande av de specifika interventionerna. Det kan vara så att de nya företagen som "bärare" av delar av evidensprogrammet kan bidra till mer effektivt och aptitligt förpackade paket på området, något som i så fall skulle kunna bidra till institutionaliseringsprocessen (även om det nödvändigtvis inte behöver betyda att de interventioner man säljer faktiskt har vetenskapligt belagda effekter). Men det huvudsakliga intrycket av enkätsvaren är trots allt frånvaron av systematik. Översättningen ser helt enkelt mycket olika ut.

De oklara gränserna för vad som kan ses som evidensbaserat framkommer också i de kvalitativa intervjuerna. Här följer tre exempel:

KBT är väl ett evidensbaserat arbetssätt just nu som ligger i ropet /.../. Systemteori också, så på det viset har jag ju kommit i kontakt med det. Man pratar mycket om det där med evidensbaserat. Att allting skall vara det idag. (Första linjens chef, kommun D)

Vi har valt ut vissa metoder /.../ och försöker hela tiden att, att hitta metoder, som passar $i$ vair verksamhet, signs of safety är en metod som /.../ de flesta haft utbildning $i$, man använder den i utredningsarbete. All personal har gåt igenom en systemteoretisk utbildning för att ge någon slags samma grund. (Andra linjens chef, kommun C)

Jag tror ju så här också att det att ju mer man fär evidensbaserad kunskap, /.../, ju mindre trendkänslig blir man /.... Att man kanske till slut ändå kan fä någon form av vägledning $i$ vad man faktiskt ska fokusera på. (Första linjens chef, kommun A)
Vi kan också här observera en kraftig utvidgning av det instrumentella innehållet i EBP som i dessa citat får omfatta allt från allmänna teoretiska perspektiv (KBT, systemteori) till bedömningsinstrument av olika slag, men också en betydande osäkerhet om vad som kan inkluderas i EBP. Här märks emellertid också en förhoppning om en minskad trendkänslighet, genom framtida bättre vägledning. En förväntan, med andra ord, om tydligare regelverk med relevans för den pågående institutionaliseringsprocessen.

\section{Diskussion}

Vad händer när ett program med hård yta och mjukt innehåll som sprids via en betydelsefull central aktör som Socialstyrelsen möter kommunala barnavårdsorganisationer? Vid första påseende kan EBP beskrivas som ett väl sammanhållet paket med ett tydligt programmatisk innehåll uppbackat av klara normativa ställningstaganden barnavårdens klienter skall få bästa möjliga insatser - och till det kopplat en uppsättning interventioner som just skall innebära en bättre, vetenskapligt förankrad social barnavård. På ett övergripande plan mottas programmet positivt av barnavårdscheferna, de allra flesta känner till programmet som det presenterats av Socialstyrelsen och nästan alla vill arbeta evidensbaserat. På det sättet kan man säga att EBP fått fäste $i$ det sociala arbetet. Det pratas om EBP och det är ett begrepp som används både utåt mot omvärlden som beskrivning av vad man gör och inåt i organisationen för att diskutera hur man skall arbeta, även om en del 
chefer, särskilt i de kvalitativa intervjuerna, problematiserar programmet.

\section{Huröversätts EBP?}

Samtidigt är det uppenbart att översättningen av ett sammansatt och motsägelsefullt program, särskilt med avseende på frånvaron av evidensbaserade metoder, inte är någon lätt sak. Hur gör då cheferna? Med risk för att gå för långt $i$ metaforerna kan man uttrycka det så att uppackandet av EBP innehåller två led av översättning, det första handlar om de programmatiska delarna, det andra om de teknologiska.

Översättning av de programmatiska delarna av EBP tycks för det första innehålla en slags begreppslig redigering, någon av cheferna vill hellre använda det bredare och mindre förpliktigande begreppet kunskapsbaserat socialt arbete. På det sättet knyter de an till en internationell diskussion där t.ex. begreppet evidence-informed practice ibland tycks användas för att åtminstone delvis luckra upp det hårda program som bland andra Socialstyrelsen spridit. Kunskapsbaserat socialt arbete och evidence-informed practice i social barnavård verkar ibland användas för att beskriva ett bredare program där all forskning eller åtminstone forskning som intresserar sig för barnavårdens utfallsfrågor $\mathrm{i}$ allmänhet, blir del i programmet (se t.ex. Littell \& Shlonsky 2010 och den engelska organisationen Research in Practice, www. rip.org.uk, om evidence-informed practice i social barnavård). Gränserna är dock påtagligt otydliga och visar på att ett ytligt sett hårt och entydigt program kan över- sättas på flera olika sätt när det möter inte bara olika organisationer utan också olika forskare.

Även om såväl enkätsvaren som intervjuerna visar på ett i huvudsak positivt mottagande av EBP, uttrycker för det andra en del av cheferna en viss skepsis inför ett hårt evidensprogram, man är orolig för alltför stor styrning, via manualer och riktlinjer och/eller att de evidensbaserade metoderna inte skall fungera för de klienter man de facto har kontakt med. Liknade farhågor märks också i svaren på enkäten, där drygt en fjärdedel av cheferna menar att socialt arbete handlar om unika möten "vilket gör vetenskapligt utformade metoder mindre användbara". Det kan kanske förefalla motsägelsefullt att cheferna samtidigt efterfrågar mer stöd för Socialstyrelsen för att välja rätt metod, men dels handlar det till stor del om andra individer än de som är metodskeptiska, dels blir det naturligtvis i högsta grad rationellt att efterfråga programmets teknologiska delar bland de som anammat dess programmatiska sidor.

Konkret tycks det redigeringsarbete barnavårdcheferna ägnar sig åt, innebära att i skilda sammanhang - t.ex. med andra chefer eller i forskningscirklar - diskutera och förhandla om vad evidens faktiskt kan vara. Men redigeringsarbetet kan också handla om att hantera och reglera motsättningar mellan å ena sidan politiker och högre chefer och å andra sidan de praktiskt verksamma socialarbetarna som intagit olika positioner, som skeptiker, entusiaster eller något mitt emellan. Det gäller att hitta möjliga kompromisser både när det gäller programmatiskt och instrumentellt innehåll. Bland de som intervjuats märks 
inga som klart satt ned foten och tydligt tagit ställning för ett hårt evidensprogram (det betyder naturligtvis inte att sådana inte finns). Huvudintrycket i intervjuerna är snarare försiktighet, långdragna förhandlingar och kompromisser för att hålla alla eller i vart fall de flesta nöjda.

Översättning av det evidensbaserade programmets teknologiska delar är naturligtvis inte lätt, när det knappast går att hitta någon pålitlig och entydig information om vad man faktiskt skall göra. En första och givetvis logisk lösning kan mycket väl vara att inte göra något alls, en fjärdedel av cheferna uppger också att de inte använder någon evidensbaserad metod. En andra och vanligare strategi tycks vara att vidga evidensbegreppet till att låta dess instrumentella delar omfatta dels olika bedömningsinstrument, dels interventioner som i olika grad har beforskats, utan att det finns särskilt starkt stöd för att de ger bättre effekter än andra interventioner (i de flesta fall finns knappast något vetenskapligt stöd alls om man efterfrågar välgjorda RCT:er eller systematiska översikter). I de kvalitativa intervjuerna märks chefernas bekymmer tydligt, man är osäker på vilka metoder som har evidens och en del vill ha tydliga anvisningar om vilka interventioner de skall använda. Somliga väljer, för det tredje, att tala om evidensprojektet framförallt som egna lokala uppföljningar av hur det går för klienterna, men även i detta avseende problematiseras EBP. I något av intervjusvaren pekar man t.ex. på att det kan vara svårt att hitta entydiga och klara förklaringar till vad eventuella skillnader i resultat beror på.

\section{Nyaföretag på EBP- marknaden}

Bland enkätsvaren kan man hitta spår av företag som säljer utbildningar i flera olika metoder till kommunerna. I sådana sammanhang blir marknadsföring om närvaron av evidens eller i vart fall forskningsstöd viktigt för företagen, men också något som kan användas av dem som köper företagens tjänster. Vi har hittills i huvudsak beskrivit EBP som spridning genom centralstaten via en centralt utformad modell (broadcasting), men här finns således också en viss närvaro av medier i form av privata företag och andra aktörer som bidrar till spridning av det som skulle kunna utgöra de teknologiska delarna. Mycket tyder på att sådana företag har fått större inflytande i den sociala barnavården idag, kanske på bekostnad av enskilda konsulter som det talades mycket om på 1980-talet (Wiklund 2011). Det finns knappast någon forskning om vad de nya medierande organisationerna betyder. En möjlig hypotes är att de (större) företagen via starkare ekonomiska och personella resurser kan bidra till mer effektivt förpackade (och säljbara) teknologiska paket, än enskilda konsulter.

Ett klart intryck från intervjuerna är att ingen av cheferna tycks mena att evidensbaserad praktik genomsyrar vardagen inom barnavårdsorganisationerna. Det är snarare något vid sidan om, något som diskuteras ungefär som andra från vardagspraktiken mer eller mindre sidoordnade frågor. På det sättet kan inte EBP beskrivas som helt institutionaliserat. För det fordras att programmet tar sig uttryck i för-givet-tagna regler, normer och rutiner 
som enskilda individer mer eller mindre automatiskt anpassar sig till. Det är långt ifrån den verklighet som cheferna beskriver. Ett vanligt antagande är att företeelser som inte är fullständigt institutionaliserade är mer känsliga för förändringar än de institutionaliserade. Sådana aktörer som är motståndare kan helt enkelt lättare ifrågasätta, förändra eller stoppa ett program som ännu inte helt har satt sig. I den meningen kan EBP sägas vara inne i en känslig fas. I samma riktning talar frånvaron av instrumentella delar som lever upp till det hårda programmet. $\AA$ andra sidan har det ju visat sig att EBP kommit att utmärkas av en påtaglig elasticitet. Det har hittills varit fullt möjligt att fylla på programmet med delar som ligger relativt långt från den teknologiska kärnan. En möjlig lösning på dagens problem är naturligtvis att programmet blir mer sammanhållet genom att de teknologiska delarna utvecklas genom att fler evidensbaserade metoder med belagda effekter kan inkluderas i programmet. Här är inte plats för att diskutera möjligheterna att förverkliga det sistnämnda. Det kan räcka med att åtminstone konstatera att det kommer att ta tid.

\section{EBPoch framtiden}

Man kan således med fog fråga sig vilken överlevnadskraft EBP-programmet har. Ponnert och Svensson beskriver hur implementeringen av Kometprogrammet efter relativt kort tid förlorade i styrka: "Efterhand minskade energin och processen avstannade när den mänskliga kraften i form av personalens entusiasm avtog till följd av tröghet i den organisatoriska strukturen och i programmet" (Ponnert \& Svensson 2011, s 182). EBP som övergripande program, med sin normativa, värdemässiga bas, har troligen större överlevnadskraft än enskilda mer eller mindre evidensbaserade interventioner. För det talar också ett allmänt ökat samhälleligt tryck i vetenskapliggörande riktning och med krav på tydligt redovisade utfall. Det är märkbart inte minst inom angränsande fält som skolan. Men fortfarande är det en i hög grad öppen fråga hur institutionaliseringsprocessen för EBP kommer att ta sig uttryck, inte minst i dess teknologiska delar.

En annan viktig slutsats av studien är att vi har kunnat konstatera att de chefer som svarat på enkäterna och de som låtit sig intervjuas, ser sig själva som högst delaktiga aktörer när det gäller att introducera nya arbetssätt, vare sig det handlar om EBP i allmänhet eller någon specifik metod. På det sättet spelar barnavårdens chefer en mycket viktig roll för hur och i vilken utsträckning EBP och andra idéer i rörelse (Røvik 2000) kommer att påverka barnavårdens organisationer och praktik. Eller annorlunda uttryckt: en viktig del i chefskapet i socialt arbete handlar just om mottagandet och översättningen av nya idéer. Hur detta går till och vilka krav och förväntningar det ställer på cheferna är ett område, med hög praktisk relevans, som borde bli föremål för fortsatta forskningsinsatser.

I forskning om idéer som sprids i socialt arbete förefaller det på basis av denna undersökning utomordentligt viktigt att ta hänsyn till hur det analyserade program- 
met eller idén ser ut. De programmatiska och instrumentella delarna och kongruensen dem emellan verkar i det sammanhanget vara en i hög grad meningsfull distinktion. På liknande sätt borde skillnaden mellan program som introduceras uppifrån och ned, respektive via kedjerörelser och med hjälp av olika typer av medierande aktörer, spela stor roll för analysen.

\section{Referenser}

Andrée Löfholm, C. Tina Olsson, T, Sundell K \& Hansson, K. (2009). Multisystemisk terapi för ungdomar med allvarliga beteendeproblem. Resultat efter två år. Stockholm: Socialstyrelsen.

Bergmark, Å. \& Lundström, T. (2002). Education, practice and research: Knowledge and attitudes to knowledge. Social Work Education, 21, 359373.

Bergmark, Å. \& Lundström, T. (2005). En sak i taget? Om specialisering inom socialtjänstens individ- och familjeomsorg, Socialvetenskaplig tidskrift, 12, 125-148.

Bergmark, Å. \& Lundström, T. (2007). Att studera rörliga mål. Om villkoren för evidens och kunskapsproduktion i socialt arbete. Socionomens forskningssupplement, 31, 4-16.

Bergmark, A. \& Lundström, T. (2008). Evidensfrågan och socialtjänsten. Om socialarbetares inställning till en vetenskapligt grundad praktik. Socionomens forskningssupplement, 29, 5 4.

Bergmark, A. Bergmark, A. \& Lundström, T. (2011). Evidensbaserat socialt arbete. Teori, kritik, praktik. Stockholm: Natur och Kultur.

Bohlin, I \& Sager, M. (red.) (2011). Evidensens många ansikten. Evidensbaserad praktik i praktiken. Lund: Arkiv.

Dellgran, P. \& Höjer, S. (2005). Rörelser i tiden. Professionalisering och Privatisering i socialt arbete. Socialvetenskaplig Tidskrift, 12, 246267.

DiMaggio, P. (1988). Interest and agency in institutional theory. I Zucker, L (red.) Institutional patterns and organizations: Culture and envi- ronment. Cambridge: Ballinger.

Grape, O., Johansson, R. \& Blom, B. (red.). (2006) Organisation och omvärld: nyinstitutionell analys av människobehandlande organisationer. Lund: Studentlitteratur.

Hansson, K. \& Olsson, M. (2012). Effects of multidimensional treatment foster care (MTFC): Results from a RCT study in Sweden. Children and Youth Services Review, 34, 1929-1936.

Johansson, R. (2001). Nyinstitutionalismen inom organisationsanalysen. Lund: Studentlitteratur.

Kaunitz, C. \& Strandberg, A. (2009). Aggression Replacement Training (ART) i Sverige - evidensbaserad socialtjänst i praktiken, Socionomens forskningssupplement, 26, 36-50.

Littell, J. \& Shlonsky, A. (2010). Toward EvidenceInformed Policy and Practice in Child Welfare. Research on Social Work Practice, 20, 723-725.

Lundström, T. (2012). Risk och riskbedömningar. I Höjer, I. Sallnäs, M. \& Sjöblom, Y. (red.) När samhället träder in: barn, föräldrar och social barnavård. Lund: Studentlitteratur.

Oscarsson, Lars (2009). Evidensbaserad praktik inom socialtjänsten - En introduktion för praktiker, chefer, politiker och studenter. Stockholm: SKL Kommentus.

Ponnert, L \& Svensson (2011). När förpackade idéer möter organisatoriska villkor. Socialvetenskaplig tidskrift, 3, 168-185.

Powell, W.W. (1991). Expanding the scope of institutional analysis. I The New Institutionalism in Organizational Analysis, Powell, W.W. and DiMaggio, P., (red). Chicago: University of Chicago Press

Røvik, K. (2000). Moderna organisationer: -tren-

Tommy Lundström \& Emelie Shanks: Hård yta men mjukt innanmäte. 
der inom organisationstänkandet vid millennieskiftet. Lund: Studentlitteratur.

Sahlin, K. \& Wedlin, L. (2008). Circulating Ideas: Imitation, Translation and Editing. I Greenwood et al (red.) The SAGE Handbook of Organizational Institutionalism. London Sage.

Seo, M. \& Creed, W.E. (2002). Institutional Contradictions, Praxis and Institutional Change: A Dialectical Perspective. Academy of Management Review, 27, 227-247.

Socialstyrelsen (2012a). Att leda en evidensbaserad praktik - en guide för chefer $i$ socialtjänsten. Stockholm: Socialstyrelsen

Socialstyrelsen (2012b). Att skapa en grund för evidensbaserad praktik - en guide för ledningen i vård och omsorg. Stockholm: Socialstyrelsen.

Sundell, K. \& Roselius, M. (red.) (2008). Att förändra socialt arbete. Forskare och praktiker om implementering. Stockholm: Gothia.

Sundell, K. \& Soydan, H. (2008). Från kunskap till praktik. I Sundell, K. \& Roselius, M. (red.) Att förändra socialt arbete. Forskare och praktiker om implementering. Stockholm: Gothia.

Wiklund, S. (2011). Individ- och familjeomsorgens välfärdstjänster. I Hartman, L (red.) Konkurrensens konsekvenser: Vad händer med svensk välfärd?. Stockholm: SNS.

\section{Summary}

\section{Managers in child welfare on translating evidence-based social work to local practice}

This article discusses how middle managers in child welfare in Swedish municipalities appraise the evidence-based social work programme and how they try to translate EBP into their local practice. The empirical material consists of questionnaires answered by 192 first and second tier managers in child welfare as well as seven qualitative interviews with managers at the same level. The material is analysed using theoretical models for idea dissemination and translation. The findings lead to a discussion on the difficulties of translating a programme in which the programmatic element does not comply with the technological content. The managers' strategies to solve this contradiction include negotiation and compromise on the programmatic parts of EBP and an expansion of what can be regarded as evidence in evidence-based practice. 